\title{
Rhodopseudomonas rutila Is a Later Subjective Synonym of Rhodopseudomonas palustris
}

\author{
AKIRA HIRAISHI, TEOFILA S. SANTOS, JUNTA SUGIYAMA,* AND KAZUO KOMAGATA \\ Institute of Applied Microbiology, University of Tokyo, Bunkyo-ku, Tokyo 113, Japan
}

\begin{abstract}
Phenotypic, chemotaxonomic, and DNA-DNA hybridization studies of strains of Rhodopseudomonas rutila Akiba et al. 1983 and Rhodopseudomonas palustris (Molisch 1907) van Niel 1944 demonstrated synonymy between the two species. We propose that they be classified into a single species, retaining the name $R$. palustris.
\end{abstract}

Rhodopseudomonas rutila is a species of phototrophic purple nonsulfur bacteria which was validly published by Akiba et al. (1) in 1983. After this publication, the species and genera of the phototrophic bacteria were rearranged by Imhoff et al. (9), and the name $R$. rutila was left as it stands because of the conformity of the taxonomic properties of this species to those of the redefined genus Rhodopseudomonas. Unfortunately, however, the original report of Akiba et al. (1) included no comparative data on $R$. rutila or on the type species Rhodopseudomonas palustris, although their descriptions are suggestive of the similarities between the two species. This situation led us to reinvestigate the characteristics of $R$. rutila compared with those of $R$. palustris and other Rhodopseudomonas species. In this paper, we demonstrate synonymy between $R$. rutila and $R$. palustris on the basis of phenotypic, chemotaxonomic, and genotypic data.

For $R$. rutila, we used the type strain only in this study because very few $R$. rutila strains are available. $R$. rutila $\mathrm{R} 1^{\mathrm{T}}$ ( $\mathrm{T}=$ type strain) was kindly supplied by $\mathrm{T}$. Akiba. To make sure, the same strain was obtained from the Japan Collection of Microorganisms, RIKEN, Wako, Japan, as $R$. rutila JCM $2524^{\mathrm{T}}$. Other strains of Rhodopseudomonas species used in this study were $R$. palustris ATCC $17001^{\mathrm{T}}$, RS22, SA37, Tb, HLS2, and UT-S2; $R$. acidophila ATCC $25092^{\mathrm{T}} ; R$. viridis ATCC $19567^{\mathrm{T}}$; and $R$. blastica NCIB $11576^{\mathrm{T}}$. $R$. palustris $\mathrm{Tb}$, HLS2, and UT-S2 were newly isolated by us from soil, photosynthetic sludge, and pond water, respectively. The sources of all other strains have been described in previous papers $(3,5)$. MYCA medium (4) was used for cultivating the organisms to be subjected to various tests. Unless otherwise noted, cells were grown anaerobically at $30^{\circ} \mathrm{C}$ under incandescent illumination (ca. 5,000 lx) in screw-capped test tubes or bottles completely filled with the medium. Morphology and related properties were investigated with a phase-contrast microscope and an electron microscope. Tests for physiological properties and photopigments were performed as described previously (5). Hydrolysis of gelatin and Tween 80 was determined for cells grown aerobically in the dark on the agar media of Hoshino and Satoh (6) and Sierra (13), respectively; the final reading was made after 7 days of incubation. Whole-cell fatty acid composition was determined as described by Ikemoto et al. (7) and Suzuki and Komagata (14). Polar lipids and isoprenoid quinones were analyzed as reported by Imhoff et al. (8) and Hiraishi et al. (3), respectively. Cellular DNA was purified by the method of Marmur (12). The moles percent guanine plus cytosine content $(G+C)$ of DNA was determined by analyzing its enzymatic hydrolysates by using a high-performance liquid

\footnotetext{
* Corresponding author.
}

chromatography method (4). DNA-DNA homology studies were performed by the quantitative dot blot hybridization method with photobiotin labeling and colorimetric detection systems $(2,4)$.

Our results for morphology and photopigments of $R$. rutila supported the previous observations (1). Namely, $R$. rutila $\mathrm{R} 1^{\mathrm{T}}$ had actively motile, subpolar-flagellated, ovoid to shortrod-shaped cells in the early stage of growth but contained nonmotile, rod-shaped cells frequently forming rosettelike aggregates in older cultures; it multiplied by budding and asymmetric cell division; and it produced deep-red-colored photosynthetic cultures which had absorption maxima at $378,462,491,524,590,802$, and $862 \mathrm{~nm}$, indicating the presence of bacteriochlorophyll $a$ and carotenoids of the normal spirilloxanthin series. In these respects, $R$. rutila is indistinguishable from $R$. palustris.

Comparative data on the physiological and biochemical characteristics of $R$. rutila $\mathrm{R} 1^{\mathrm{T}}$ and $R$. palustris strains are shown in Table 1 . The present results obtained with $R$. rutila differed in part from the report of Akiba et al. (1). They reported that $R$. rutila was negative for photoassimilation of acetate and benzoate as carbon sources and for requirement of vitamins as growth factors. However, we found $R$. rutila $R 1^{T}$ to grow well on both acetate and benzoate under phototrophic conditions and to require $p$-aminobenzoate as the sole growth factor. Our results also conflicted with those of the original description in some other phenotypic tests, such as fructose assimilation, thiosulfate utilization, and Tween 80 hydrolysis.

The phenotypic characteristics noted above (e.g., acetate and benzoate utilization) have been diagnostically important for differentiating $R$. rutila from $R$. palustris (15). However, the results reported here clearly show that the two species are identical with respect to physiological and biochemical characteristics, as well as morphology and photopigments.

Previous reports have shown that, like $R$. palustris, $R$. rutila contains ubiquinones with ten isoprene units as the major quinones $(1,3,10)$ and has unsaturated straight-chain fatty acids and 3-hydroxy fatty acids with $C_{18: 1}$ and $C_{14: 0}$ predominating, respectively (10). These results were entirely confirmed by the present study. Similarities between the strains of the two species were also observed in that both contained cardiolipin, phosphatidylethanolamine, phosphatidylcholine, phosphatidylglycerol, and an aminophospholipid as the major phospholipids.

The results of DNA base composition and DNA-DNA hybridization studies are shown in Table 2 . $R$. rutila $\mathrm{R}^{\mathrm{T}}$ had the DNA base composition with a $\mathrm{G}+\mathrm{C}$ content of 65.5 mol\%. This value is $2 \%$ lower than that reported by Akiba et al. (1). $R$. rutila $\mathrm{R}^{\mathrm{T}}$ was genetically identical to $R$. rutila JCM $2524^{\mathrm{T}}$, as was naturally expected, and was closely 
TABLE 1. Physiological and biochemical characteristics of $R$. rutila compared with $R$. palustris

\begin{tabular}{|c|c|c|c|}
\hline \multirow{3}{*}{ Characteristic } & \multicolumn{3}{|c|}{ Result $^{a}$ for: } \\
\hline & \multicolumn{2}{|c|}{ R. rutila $\mathrm{R}^{\mathrm{T}}$} & \multirow{2}{*}{$\begin{array}{l}\text { R. palustris } \\
\text { (6 strains) }\end{array}$} \\
\hline & $\begin{array}{l}\text { Akiba } \\
\text { et al. }\end{array}$ & $\begin{array}{l}\text { This } \\
\text { study }\end{array}$ & \\
\hline \multicolumn{4}{|c|}{$\begin{array}{l}\text { Photosynthetic electron donors } \\
\text { and carbon sources }{ }^{b}\end{array}$} \\
\hline Formate & - & - & - \\
\hline Acetate & - & + & + \\
\hline Propionate $(0.05 \%)$ & - & $(+)$ & $(+)$ \\
\hline Butyrate $(0.05 \%)$ & + & + & + \\
\hline Caproate $(0.05 \%)$ & + & $(+)$ & $(+)$ \\
\hline Pyruvate & + & + & + \\
\hline Lactate & + & + & + \\
\hline Citrate & $(+)$ & $(+)$ & $(+)$ \\
\hline Succinate & + & + & + \\
\hline Fumarate & + & + & + \\
\hline Malate & + & + & + \\
\hline Malonate & + & + & + \\
\hline Tartrate & - & - & - \\
\hline Benzoate $(0.05 \%)$ & - & + & + \\
\hline Glucose & - & - & - \\
\hline Fructose & $(+)$ & - & - \\
\hline Mannitol & - & - & - \\
\hline Methanol & - & - & - \\
\hline Ethanol & + & + & $\pm(5)$ \\
\hline Glutamate & + & + & + \\
\hline Casamino Acids & + & + & + \\
\hline Sulfide $(0.5 \mathrm{mM})^{c}$ & - & $(+)$ & $\pm(5)$ \\
\hline Thiosulfate ( $2 \mathrm{mM})$ & - & + & + \\
\hline Growth with $3 \% \mathrm{NaCl}$ & - & - & - \\
\hline Vitamin required & - & $p$-ABA & $p$-ABA \\
\hline Gelatin hydrolysis & - & - & - \\
\hline Tween 80 hydrolysis & - & $(+)$ & $(+)$ \\
\hline
\end{tabular}

${ }^{a}$ Symbols and abbreviations: + , positive; $(+)$, weakly positive; - , negative; $p$-ABA, $p$-aminobenzoic acid. Numbers in parentheses indicate the number of strains giving positive reactions when the response varied among strains.

${ }^{b}$ The concentration of substrates added was $0.2 \%$, unless otherwise noted. Organic acids were added as their sodium salts.

$c 0.01 \%$ yeast extract was present.

related to $R$. palustris strains at a homology level of more than $78 \%$. Therefore, it is logical to regard these species as a single species in the light of the phylogenetic concept of a species based on DNA-DNA reassociation levels (16). On the other hand, the $R$. rutila DNA showed very low homologies to the DNAs of the strains of other Rhodopseudomonas species.

The results reported in this paper indicate that there are no differences in phenotypic, chemotaxonomic, or genotypic properties between $R$. rutila and $R$. palustris, in contrast to the report of Akiba et al. (1). Since the type strain of $R$. rutila we studied was obtained from two different sources, the possibility that we mislabeled the strain can be excluded completely. Thus, the discrepancy between the observations of Akiba et al. (1) and ours results from their misreading of the tests. In conclusion, $R$. rutila Akiba et al. 1983 is a later subjective synonym of $R$. palustris (Molisch 1907) van Niel 1944 , and they should be regarded as a single species. Since the name $R$. palustris has priority over $R$. rutila under the International Code of Nomenclature of Bacteria (11), we propose that the former name be retained, with ATCC 17001 as the type strain.
TABLE 2. DNA-DNA relatedness between strains of $R$. rutila and other Rhodopseudomonas species

\begin{tabular}{|c|c|c|c|c|}
\hline \multirow[b]{2}{*}{ Species } & \multirow[b]{2}{*}{ Strain } & \multirow{2}{*}{$\begin{array}{c}\mathrm{G}+\mathrm{C} \\
\text { content } \\
(\mathrm{mol} \%)\end{array}$} & \multicolumn{2}{|c|}{$\begin{array}{c}\% \text { Homology to } \\
\text { biotinylated DNA from: }\end{array}$} \\
\hline & & & $\begin{array}{l}R \text {. rutila } \\
\mathrm{R}^{\mathrm{T}}\end{array}$ & $\begin{array}{l}\text { R. palustris } \\
\text { ATCC } \\
17001^{\mathrm{T}}\end{array}$ \\
\hline \multirow[t]{2}{*}{ R. rutila } & $\mathrm{R} 1^{\mathrm{T}}$ & 65.5 & 100 & 80 \\
\hline & JCM $2524^{\mathrm{T}}$ & 65.3 & 102 & 83 \\
\hline \multirow[t]{6}{*}{ R. palustris } & $\operatorname{ATCC} 17001^{\mathrm{T}}$ & 65.0 & 78 & 100 \\
\hline & RS22 & 64.9 & 91 & 94 \\
\hline & SA37 & 64.6 & 83 & 88 \\
\hline & $\mathrm{Tb}$ & 64.6 & 87 & 90 \\
\hline & HLS2 & 64.8 & 79 & 85 \\
\hline & UT-S2 & 64.5 & 78 & 81 \\
\hline R. acidophila & ATCC $25092^{\mathrm{T}}$ & 65.1 & 7 & $\mathrm{ND}^{a}$ \\
\hline$R$. viridis & ATCC $19567^{\mathrm{T}}$ & 66.5 & 10 & ND \\
\hline$R$. blastica & NCIB $11576^{\mathrm{T}}$ & 65.5 & 2 & ND \\
\hline
\end{tabular}

${ }^{a} \mathrm{ND}$, not determined

\section{REFERENCES}

1. Akiba, T., R. Usami, and K. Horikoshi. 1983. Rhodopseudomonas rutila, a new species of nonsulfur purple photosynthetic bacteria. Int. J. Syst. Bacteriol. 33:551-556.

2. Ezaki, T., S. Dejsirilert, H. Yamamoto, N. Takeuchi, S. Liu, and E. Yabuuchi. 1988. Simple and rapid genetic identification of Legionella species with photobiotin-labelled DNA. J. Gen. Appl. Microbiol. 34:191-199.

3. Hiraishi, A., Y. Hoshino, and H. Kitamura. 1984. Isoprenoid quinone composition in the classification of Rhodospirillaceae. J. Gen. Appl. Microbiol. 30:197-210.

4. Hiraishi, A., Y. Hoshino, and T. Satoh. 1991. Rhodoferax fermentans gen. nov., sp. nov., a phototrophic purple nonsulfur bacterium previously referred to as the "Rhodocyclus gelatinosus-like"' group. Arch. Microbiol. 155:330-336.

5. Hiraishi, A., and H. Kitamura. 1984. Distribution of phototrophic purple nonsulfur bacteria in activated sludge systems and other aquatic environments. Bull. Jpn. Soc. Sci. Fish 50:1929-1937.

6. Hoshino, Y., and T. Satoh. 1985. Dependence on calcium ions of gelatin hydrolysis by Rhodopseudomonas capsulata but no Rhodopseudomonas gelatinosa. Agric. Biol. Chem. 49:33313332.

7. Ikemoto, S., K. Katoh, and K. Komagata. 1978. Cellular fatty acid composition in methanol-utilizing bacteria. J. Gen. Appl. Microbiol. 24:41-49.

8. Imhoff, J. F., D. J. Kushner, S. C. Kushwaha, and M. Kates 1982. Polar lipids in phototrophic bacteria of the Rhodospirillaceae and Chromatiaceae families. J. Bacteriol. 150:11921201

9. Imhofi, J. F., H. G. Trüper, and N. Pfennig. 1984. Rearrangement of the species and genera of the phototrophic "purple nonsulfur bacteria." Int. J. Syst. Bacteriol. 34:340-343.

10. Kato, S., T. Urakami, and K. Komagata. 1985. Quinone systems and cellular fatty acid composition in species of Rhodospirillaceae genera. J. Gen. Appl. Microbiol. 31:381-398.

11. Lapage, S. P., P. H. A. Sneath, E. F. Lessel, V. B. D. Skerman, H. P. R. Seeliger, and W. A. Clark (ed.). 1975. International code of nomenclature of bacteria. American Society for Microbiology, Washington, D.C.

12. Marmur, J. 1961. A procedure for the isolation of deoxyribonucleic acid from micro-organisms. J. Mol. Biol. 3:208-218

13. Sierra, G. 1957. A simple method for the detection of lipolytic activity of microorganisms and some observations on the influence of the contact between cells and fatty substrates. Antonie van Leeuwenhoek 23:15-22.

14. Suzuki, K., and K. Komagata. 1983. Taxonomic significance of cellular fatty acid composition in some coryneform bacteria. 
Int. J. Syst. Bacteriol. 33:188-200.

15. Trüper, H. G., and J. F. Imhoff. 1989. Genus Rhodopseudomonas Kluyver and van Niel in Czurda and Maresch 1937, $119^{\mathrm{AL}}$, p. 1672-1677. In J. T. Staley, M. P. Bryant, N. Pfennig, and J. G. Holt (ed.), Bergey's manual of systematic bacteriology, vol. 3. The Williams \& Wilkins Co., Baltimore.
16. Wayne, L. G., D. J. Brenner, R. R. Colwell, P. A. D. Grimont, O. Kandler, M. I. Krichevsky, L. H. Moore, W. E. C. Moore, R. G. E. Murray, E. Stackebrandt, M. P. Starr, and H. G. Trüper. 1987. Report of the Ad Hoc Committee on Reconciliation of Approaches to Bacterial Systematics. Int. J. Syst. Bacteriol. 37:463-464. 